\title{
THE BIRTH OF POP. THE SOUNDSGAPES OF THE EARLY SIXTIES IN ITALIAN GINEMA AND TELEVISION
}

\author{
Massimo Locatelli
}

\section{INTRODUCTION}

In post-WWII Europe, film culture related in many different ways to a wide range of modern cultural practices. It had the emerging pop music industry at its centre and this was revolutionizing the landscapes and soundscapes we live in. The aim of my contribution is to delve into these related practices, taking the Italian case as my focus. I will explore its crucial journey to mediatization from the Fifties to the Sixties and will argue that it offers an exemplary trajectory for its (apparently excessive) foregrounding of music and sounds both in national film culture and in the transnational mediascape.

I will examine the well-known performer, Adriano Celentano, as my case study. Celentano debuted as the Italian rocker par excellence at the end of the Fifties, starting an impressive and unprecedented career in our national pop culture. ${ }^{1}$ As a singer, songwriter, comedian and actor (later also as a successful television host) he posited himself at the centre of the process of integration of the media industries that characterized the on-going modernization of Italy. Celentano is crucial in my view because he is part of the generation that configured Italy's first basic encounter with pervasive modern lifestyles and media technologies. A conservative culture was nudged, because of this, towards change.

\section{THE TUNING OF THE COUNTRY}

To begin, we need to define the economic and political context of the time, sketching its social and technological values. We could map three main production lines: the multinational electrical companies, the small and medium national entrepreneurs, and the state owned broadcaster. $^{2}$

Italy's audiovisual media industries depended on the multinational media system from its beginning. In the Twenties, radio equipment was mainly furnished by Western Electrics, based

1 There are many different biographical contributions on Celentano: see a.o. Celentano 1991, Cotti 2007, Eboli 2005, Fittante 1997, Perini 1999.

2 I could thoroughly describe these processes in Locatelli 2004 and Locatelli 2009. 
in Milan since the telegraph era, and by General Electrics, which established in the same city a local branch, Compagnia Generale di Elettricità (CGE) in 1921, in order to produce locally and to avoid heavy customs duty. By the time of the launch of sound film, CGE marketed its own radio products and the theatrical device RCA Photophone, commercialized in our country as Fotofono CGE. It thereby managed to control a fairly good market quote (Mannino Patané 1943, 472-480), to the detriment of Western Electrics and other European companies. Well-known political reasons caused a heavy "germanization" of the market towards the end of the Thirties, but the end of the war re-established US political and economical patronage. A key event was the foundation in 1951 of the Italian branch of RCA (RCA Italiana) in Rome. This positioned our country within the wider framework of new media politics, which - albeit substantially political: the maintenance of Italy in the Western sphere - also began to be thought of as a network of different technological platforms (as in the USA). RCA Italiana thus began to support not only US-American technologies, but also US-American pop cultural products like boogie-woogie, cha-cha-cha and other Latin American rhythms, shortly later Elvis Presley and the first rock'n'roll hits.

Concurrently, mainly in the northern part of the country, a number of small and medium entrepreneurs had been competing on the national media market since the Fascist era. They took up the challenge of modernizing the music branch by reaching a higher technological performance in the production of media tools. This was achieved first producing radios, portable disc players, tape recorders, sound amplifiers for theatrical and home reproduction, and subsequently (that is, after the mid-Fifties), televisions, portable radio receivers, and hi-fi systems. Some of these could be exported worldwide (Allocchio-Bacchini, Cinemeccanica, Ducati, Geloso, Lesa, Magneti Marelli were the key trademarks).

Changing market conditions similarly compelled music publishers to shift the production of music content from being centered on sheet publishing to recording and selling broadcasting rights. In 1958, the heir to Italy's most renowned music publisher, Nanni Ricordi, who previously worked for RCA Victor in New York, founded in Milan the first modern national recording company, Dischi Ricordi. He commercialized 45rpm records of the most popular Italian singers and thus promoted and advanced the record market. Celentano's career started in a similar context: he had been noticed by the press first in 1957, while performing live in music venues in the Milan area with a rock cover band, the Rock Boys. A Milan-based Swiss record producer, Walter Guertler, launched him as a cover singer, as he could easily perform a variety of modern USand Latin-American genres, starting from Haley, Richards and Presley covers, but including also tango and calypso. In 1958 Guertler too launched a new label with all-Italian rock songs, Jolly, and Celentano immediately succeeded with his own hits, winning a song contest in Ancona with "Il tuo bacio è come un rock" [Your kiss is like rock'n'roll]. This was the beginning of a triumphant series of successes: in 1961 Celentano could also start an independent record label of his own, II Clan, surprisingly earning in this way the same success he enjoyed before.

Meanwhile, the development of radio and television programming was taking place with the same nationalist and conservative character radio broadcasting had under the fascist regime. The old infrastructure, previously called EIAR, was relabeled after the war as RAI, and financed in order to complete the aerial covering of the country and to start with regular television broadcasting (under a complete government control) in 1954. To appeal the public, our national television made wide use of popular Italian songs in radio programming and television music shows like II musichiere (Programma Nazionale RAI, 1957-1960) and Canzonissima (Programma Nazionale RAI, 1958-1962/1968-1974), as well as in the commercials show Carosello (Programma Nazionale RAI, 
1957-1977). ${ }^{3}$ Even more successfully, RAI patronized the first great Italian modern media event, the national song contest Festival di San Remo (since 1951 on radio, since 1955 on tv). ${ }^{4}$ Celentano made his first guest appearance in television in 1959 as a rock cover singer jumping out from the back of a jukebox in II musichiere, but as late as in 1961 he was already starring as a feature singer at San Remo and in the Canzonissima competition, placing second at both contests.

Although for different if not competing interests, the three great players in the media market, the US-American media industry, the State funded broadcasting, and the growing Italian small and medium media entrepreneurship, were thus together aiming for a convergence of marketed technologies. In 1958, the commercial launch of the "microgrooves", the $45 \mathrm{rpm}$ and the long-playing $331 / 3 \mathrm{rpm}$ records, supported by the contemporary spreading of the Wurlitzer juke-boxes, made it possible to have all efforts converge on the song-form.

Not surprisingly, during the Fifties film music played a central role in marketing records. The fragmentary charts we have of the period show how people appreciated hearing film-stars sing. RCA Italiana even tried to transform Sofia Loren into a singer, publishing on a 45rpm record the main song from her English-speaking debut, Boy on a Dolphin, by Jean Negulesco, 1957 (Greek lyrics and title: "S'Agapo"). Indeed, Italian cinema had relied on popular songs and Opera-films since the very beginning of the sound era. But by 1955, the growing fortune of the music business pushed our film industry towards a deepening of the musical structure of many films, adding to the tenors of the Opera-films, or to the nicely singing actors of the romantic comedy, emergent Sanremo stars like Nilla Pizzi (who won the 1951 and 1952 editions) or Claudio Villa (winner in 1955, 1957 and 1962).

Marino Girolami, a young director trained in Opera-films, started a series of comedies which could be recognized by the press as film musicali. After the unexpected success of the American rock'n'roll films in late 1956, the production of pop-musical comedies became a necessity in Italy as anywhere: Girolami alone directed in 1957 six titles starring Claudio Villa. Shortly later, genre-movies director Lucio Fulci and film musicali producer Giovanni Addessi invented a new kind of musical comedy, which would soon be labeled as musicarello (a musical Carosello). Representative of this was their first joint feature film, I ragazzi del jukebox (1959), consisting of a musical compilation, full of young singers and focused on the opposition between the older and the younger generation, between the traditional melodic music and the new American styles in music and fashion. The film took its title from the B-side of Adriano Celentano's single "Il tuo bacio è come un rock" - that is "I ragazzi del jukebox" [The jukebox youngsters]. Celentano played himself and the difference between him and the old melodic singer was explicitly signalled by the voice over, which jeered the old dethroned king of popular music, Claudio Villa, and sympathized with the usurper Celentano and his friends.

Film was exploited in order to make Italians familiar not only with new sounds, but also with new soundscapes. This was particularly true with regards to the growth of undistorted power of acoustic amplification systems. New ways of experiencing sound emerged also through high fidelity and stereophony. ${ }^{5}$

Amplification technologies heavily impacted the lived environment. Throughout the country, the building of television aerials made it possible to transmit radio broadcasting with the higher sonic definition of the modulation of frequency system. FM waves, portable

3 On the history of Italian television, see Grasso 2004, Menduni 2006, Monteleone 1992, Morcellini 2000.

4 On the history of the Festival, see Facci and Soddu 2013.

5 I could discuss this issue with more details in Locatelli 2011. 
disc-players, tape recorders and juke-boxes got Italian audiences accustomed to hearing reproduced music everywhere. This enabled the success of transistor radio receivers too, after the launch of the milestone Sony TR-610 receiver in 1958. Nevertheless, sound reproduction technologies becoming part of our daily experience and providing higher standards of networking capabilities was felt as a defining trauma of modernity, as they were related to the loss of natural sounds and the pervasiveness of industrial noise: ${ }^{6}$ fears that were to be best expressed by Michelangelo Antonioni in Deserto rosso (1963). ${ }^{7}$ Popular culture addressed these changes too, although in a typically parodic way. I ragazzi del juke-box stood out as a really odd but paradigmatic case, as the voice-over narrator was personified by a jukebox. In a 1964 heist movie parody, Super-rapina a Milano, the first film Celentano directed on his own (uncredited director: Piero Vivarelli), media pervasiveness is openly and playfully recalled, as the story at the end reveals itself to be a film-in-film structure. Also, in a striking scene where the fictional character played by Celentano sits at the poker table looking sideways at a television show, featuring Celentano as himself performing "L'angelo custode" [The guardian angel], we see the same self-referential structure mirrored again. Finally, before the crucial heist, all the mobster's watches are revealed to be unreliable and the mob can get on time at the heist scene only by following the national radio time-signal. The radio receiver is a modern portable transistor receiver, apparently the only legitimate form of organization left.

Other technological enhancements of the media market included indeed the electrification of instruments like the guitar, which permitted the juvenile music revolution we know as rock'n'roll, and the bass, a basic enhancement for the beat generation and any following pop musical phenomenon. In opposition to the traditional Opera-films and the first film musicali of the mid-Fifties, the musicarelli clearly exploited the new electric sounds that theatrical sound amplifying systems could by then reproduce. Not only was the electric guitar always physically in the middle of any musical sequence, but the exciting qualities of its high frequencies were often combined with strong rhythmic elements, including of course the rhythmic section, but also shouts, cries, bell rings, and any sort of noises, crashes, hammering, beating of similar frequency and volume, turned into narrative as the youngsters' jokes. By 1963, Italian film music composers like Piero Piccioni introduced in their scores the newborn electric bass, definitively extending the frequency spectrum also to its lower values. In Super-rapina a Milano, the arranger of the Clan etiquette Mariano Detto, who composed the film track, exploited the vibrating pulsations of the electric bass with a previously unheard Motown-inspired scoring excerpt for a helicopter shot flying over the city of Milan - Celentano would assiduously insist on these sounds in the Seventies.

It's noteworthy to add that this technological and experiential shift is not to be interpreted as homogeneous and relentless: for a long while, it provoked misunderstandings, and Italians advanced with caution towards it. The merging of the sources of sound, the radical changing of the soundscape, the increasing and frightening presence in absence of "acousmatic" sounds that scholars like Schaeffer, Schafer and Chion have so convincingly described (Schaeffer 1946, Schafer 1977, Chion 1982, 1985 and 1990) was to be accepted with our typical national distrust and confusion. An example is offered by a 1963 Celentano musical comedy, Uno strano tipo (directed by Lucio Fulci). Here again Celentano plays himself and a fictional character at the same time: Peppino, a dumb double of the real Celentano on tour, is forced by situation to take the place of the singer in front of the public of a night club; the

6 See e.g. Briani 1955

7 On Antonioni and Deserto rosso, Calabretto 2007 and Calabretto 2010. 
only solution for the club owner is to make him sing in playback, playing "Amami e baciami" [Love me and kiss me] on a portable disc-player in the backstage. But the sudden start of the record surprises Peppino, who can only try to awkwardly mimic the real performer, out of sync and neither correctly singing in the microphone. Real movie-goers could laugh, reminded as well of some weaknesses of contemporary television performances, and of the deficiencies of technological media. But the fictional audience in the night-club seemed to appreciate the "live" performance show of the portable record-player: and, willy nilly, Italians began actually to do the same. The original performance ceased to be connected to popular cultural experiences, which in turn could be integrated into a networked production line, granted both by a corporeal double and its disconnected recorded voice.

By the end of the Fifties, different ways of consumption were identifiable within the context I'm sketching out. All of them were still socially marked, but for the first time in our country media consumption was supposedly its way to being linked to individual, experiential styles (Schulze 1992). On one level, the notion of High fidelity branded a group of distinction practices for a technocratic upper class, owning home technologies like the hi-fi systems and high-cultural goods, like experimental music, attendance at the Opera, intellectual debates and literary and critical reviews. On another level, we can recognize the upper middle class, mainly consisting of male engineers, who owned the technical know-how (do-it-yourself technologies, amateur clubbing, technical reviews) that I argue fueled the economic boom by transforming it from a mere economic and industrial growth phenomenon into an widespread and shareable social discourse. On a final level, film, portable record-players, jukeboxes, and so on, were occasions for participative consumption for the popular class, still wavering at the movies, but ready to rush at the soon-to-come mass production.

\section{THE CURVES OF THE POP SINGER}

The following step will lead us into a discussion of representation politics. It's surely not a surprise that pop music heavily interfered with the public sphere in Western Europe after the recorded and amplified sound revolution of the Twenties. Italy was no exception. Audiovisual media production in Fascist and post-Fascist time were carefully observed and criticized both by intellectuals and by authorities, since they could on the one side confirm conservative narratives, and on the other, at the same time, play with the menacing fire of the exposed bodies of male and female stars. But how could the Italian audiovisual industry negotiate between these extremes?

Until the Fifties, all the experiential, social and economic sets of practices which I briefly and in a sketchy way referred to as modern lifestyles, could be gradually incorporated in our country's imagination by means of separating the represented life-worlds of the Italian viewer from the fascinating but dangerous foreignness embodied by aristocratic characters with international connections. The sexual allusion of exotic dance-styles, for example, is typically left to a foreign star, or to Italian characters who were punished by narrative destiny, as in the case of Anna, Alberto Lattuada's 1952 film success, where Silvana Mangano famously dances the provoking mambo "El Negro Zumbon" [spanish: The nigger Zumbon]. Italians had instead to perform Italian qualities, like Latin romance or melodic tunes in the Belcanto tradition. Making good use of his enormous popularity within lowbrow masses in Central and Southern Italy, Claudio Villa for instance continuously repeated in Girolami's film musicali the eternal stereotype of the eversinging Italian man of the people, humble and patient, flirting with foreign beauties; he thus offered a stereotypical and, I may say, self-indulgent representation of national manhood. 
But neither the mambo nor the Belcanto were actually ballabili in the operatic sense: i.e. music meant to be sung and/or danced by all the participants to the piece. As the classic performer stood in the middle of the always applauding crowd, the community depicted in Anna, or imagined by the RAI management, was no corps de ballet [literally, a dancing body], and we could consequently assume that neither the Sanremo ceremony nor the popular dances coming from America in the Fifties could be interpreted as "national-popular" (Gramsci 1950): there was a lack of bodily and participatory rituals, and this was exactly what the new collective spaces and identities of the time were asking for.In fact, after 1958, when the sons and daughters of a new petite bourgeoisie came to their musical age, and could explore the new soundscapes that were offered them, a new social player could be recognized, reconfiguring the same experiential set and the same technological devices through new ways of consumption and new cultural goods, like pop music reviews, juvenile magazines, and pop music films (Piredda 2011, Toschi 2011). The Youth were sometimes thought to look as they do in the opening sequence of the first I ragazzi del juke-box sequel, Urlatori alla sbarra (Lucio Fulci, 1960), where a Milanese dude, Celentano, plays rock'n'roll for a dancing garage party in US-American college uniform. This is standard Americanism. Otherwise, they could be felt to be dangerous, mod or teddy-boy like rebels, as in the scandal mongering press reports of the first rock'n'roll events, in 1957, or in staid television reports like Giovani d'oggi (Carlo Alberto Chiesa, Programma Nazionale RAl, 1958). Celentano, taking part in these "infamous" events from the beginning, fitted perfectly in these pictures. Borrowing Elvis Presley gestures, Celentano participated in a 1958 Jerry Lewis imitator contest, and began performing a sort of dance show while singing, substituting a real dancer who he had hired for his first season of concerts. His care for the bodily dimensions of the show and his being a supple and double-jointed dancer earned him the nickname II Molleggiato [the springy or elastic one]. Also his voice could be misperceived, as it happened to melodic singer Luciano Tajoli, guest star at the previously mentioned tv-show II musichiere, who, blindfolded for the show's purposes, took the debutant Celentano for the real Presley. Such a bodily and vocal performance on the one side ostensibly expressed the myth of Youth: just think of the springy, elastic, but uneducated connotations of Celentano's dance. ${ }^{8}$ But on the other side it revealed the emergence of a new kind of masculinity, no longer based on the strength of a detached virility, but on the capacity to relate to others in a dynamic, participatory space, where femininity itself could be built anew. In the same opening sequence of Urlatori alla sbarra, Mina, the coolant singer, was the one, who finally drove the action and led the gang - Celentano's rude and goodhearted maleness notwithstanding. ${ }^{9}$ His springy sexuality threatened only adult morality, and not femininity.

In this field of contradictions a new kind of performer could yet emerge. In 1959 Fellini asked Adriano Celentano to interpret himself and sing a rock-hit, "Ready Teddy", in a famous night-life sequence of La dolce vita: Celentano exploded with his energy, ending exhausted in knees; his bodily presence seemed alien to the decadent, intellectual life-world of Marcello Mastroianni's oldfashioned character. In 1961 Valerio Zurlini used Celentano's "Impazzivo per te" [Crazy for you] for a key-sequence of his masterpiece La ragazza con la valigia: on a hotel's terrace, in summer, old-fashioned boy Lorenzo (Jacques Perrin), is seduced by the provoking and unconventional beauty of the dancer Aida (Claudia Cardinale). As Buzzi states: "We do not really see Aida, but the personification of a new society, which attracts and simultaneously frightens Lorenzo, like a mermaid, a beautiful girly body with a voice singing like nobody did before" (Buzzi 2013, 142, my transl.).

8 Celentano likes to be nicknamed as "The King of the Ignorants" (Celentano 1991).

9 Their parallel careers could be entirely compared this way. On Mina, see Fabbri and Pestalozza 1998. 
Auteur films could more clearly, directly and with efficacy depict cultural changes: Germi, Lattuada, Pietrangeli, for example, magnificently exploited pop songs from then on. Musical comedies stand nonetheless as an exemplary trajectory in this wider process, as they crucially stood at the juncture between the juvenile and technological imaginary. Consequently, they expressed cultural models for the building of national identity, gender identity, and citizenship. Pop musical audiovisual productions, for example, negotiated conservative public values and virtues and the raising pressure embodied by US-or Latin-American pop music. This took place on the one side as a confrontation of a juvenile musical iconography with traditional narrative themes: in a paradigmatic sequence of Uno strano tipo, Celentano needs to nurse the baby of his dumb double Peppino, and thus takes the guitar and invents a rocking lullaby in order to attend his paternal duty without receding from his performing persona. On the other side, the negotiation also took place at the level of musical composition and performance, since Celentano often performed "adult" rhythms and also adapted his costume. He did this, for example, in the final sequence of the same film, a concert of the real Celentano, wearing suit and tie. In this same paradigmatic example, when the rocker plays a tango, "Grazie, prego, scusi" [Thank you, please, I'm sorry], the strength of his performance forces a group of tough ladies, young Celentano fans in Marlon Brando outfits, to trace a cha-cha-cha step. Their leader looks angry at them, and they try to remedy (and literally re-mediate), shifting to a twist...

If only on behalf of a mix of economic and political interests, and with different responses in different social groups, in this merging of media experiences there were processes of community-building through imagination at play. Italians could still - while listening and watching pop music in film and television - imagine being part of a national community, and not just spectators.

Voice and sound could thus both appeased the traumata of modernity and exceeded limits, crossing national borders, trespassing social differences, obliterating the separation between public and private, and the singer's audiovisual performance lost its symbolic function as an established signifier of Nation and Manhood. In pop musical productions the audiovisual body was not any more destined to inform, but to perform experience, and became a tool of a mediatization process: through media technology it turned into a networked actor, supporting a process of juvenile regeneration and also, at the same time, actively re-constructing in new forms the ideological class distinction which popular music once merely reflected. The mission of the performer was not any more the spreading of a given national identity and of its social norms and classes, but the inclusion of different social agents and life-styles into a shared public space, a modern country.

\section{SAVE THE LAST DANCE}

The experiential environment I have explored was built between the end of the Fifties and the mid-Sixties. It was multilayered, fragmented, contradictory, and indeed confused, at all levels - the economic, the social, the technological, and the representational one. This gives us a clue as to why it could not be transformed into a homogeneous collective memory, despite its enduring performative strength. Pop musical memories have been de-historicized, they belong to the individual, and they can be reused (re-sung) in any life situation and also re-marketed in any television format or new media platform. Celentano himself refashioned his character convincingly, adapting it to the different, changing political climates and media environments he survived and probably mastered. This seems to be the Italian way of pop. 


\section{BIBLIOGRAPHY}

BUZZI, Mauro, La canzone pop e il cinema italiano. Gli anni del boom economico (1958-1963), Kaplan, Torino, 2013.

CALABRETTO, Roberto, Lo schermo sonoro. La musica per film, Marsilio, Venezia, 2010.

- "Michelangelo Antonioni e la musica", in G. Martini (ed.), Michelangelo Antonioni, Falsopiano, Bologna, 2007, pp. 18-41.

CELENTANO, Adriano, II re degli ignoranti, Mondadori, Milano, 1991.

CHION, Michel., La voix au cinéma, Editions de L'Etoile, Paris, 1982.

- Le son au cinéma, Editions de L'Etoile, Paris, 1985.

- L'audio-vision. Son et image au cinéma, Nathan, Paris 1990.

COTTI, Sergio, Adriano Celentano (1957-2007): cinquant'anni da ribelle, Editori riuniti, Roma, 2007. EBBOLI, Francesca, Adriano Celentano - Dalla via Gluck a RockPolitik, Edizioni Ferdinando Lo Vecchio, Genova, 2005.

FABBRI, Franco and PESTALOZZA, Luigi (eds.), Mina. Una forza incantatrice, Euresis, Milano, 1998.

FACCI, Serena and SODDU, Paolo (eds.), II Festival di Sanremo. Parole e suoni raccontano la nazione, Carocci, Roma, 2011.

FITTANTE, Aldo, Questa è la storia... Celentano nella musica, nel cinema e in televisione, II Castoro, Milano, 1997.

GRAMSCl, Antonio, Letteratura e vita nazionale, Einaudi, Torino, 1950.

GRASSO, Aldo, Storia della televisione italiana, Garzanti, Milano, 2004.

LOCATELLI, Massimo, "Un dolce inganno. II sonoro nel cinema italiano dalla ricostruzione al boom", in Comunicazioni Sociali, 1, 2004, pp. 62-70.

- "Paesaggi sonori. Cinema, media e tecnologia in Italia dalla rivoluzione sonora al boom economico", in L. CavalliSforza(ed.), La Cultura Italiana, vol. IXedited byU. Volli, UTET, Torino 2009.

- "Il cinema italiano del dopoguerra tra alta fedeltà e stereofonia", in Comunicazioni sociali, 1, 2011, pp. 7-15.

MANNINO PATANE', Gaetano, Il cine sonoro - passo normale. Proiezione, acustica, Hoepli, Milano 1943.

MENDUNI, Enrico, "La nascita della televisione in Italia", in: A. Cardini (ed.), II miracolo economico italiano (1958-1963), II Mulino, Bologna, 2006, pp. 115-139.

MONTELEONE, Franco, Storia della radio e della televisione in Italia. Società, politica, strategie, programmi (1922-1992), Marsilio, Venezia, 1992.

MORCELLINI, Mario, Mediaevo. Tv e industria culturale nell'Italia del XX secolo, Carocci, Roma, 2000.

PIREDDA, Maria Francesca, "Alza il volume! Tecnologie, spazi e pratiche musicali dei giovani nell'industria culturale italiana tra gli anni Cinquanta e Sessanta", in Comunicazioni sociali, 1, 2011, pp. 58-65.

SCHAFER, Robert Murray, The Tuning of the World, McClelland and Steward Ltd., Toronto, 1977.

SCHAEFFER, Pierre, "L'élément non visuel au cinéma", La Revue du cinéma, 1, 1946, pp. 45$48 ; 2,1946$, pp. 62-65, 3, 1946, pp. 51-52.

TOSCHI, Deborah, "Maschere e vocalità di una ragazza yé-yé: il caso di Rita Pavone", in Comunicazioni sociali, 1, 2011, pp. 74-83.

PERINI, Bruno, Adriano, come un rock, Rizzoli, Milano, 1999.

SCHULZE, Gerhard, Die Erlebnisgesellschaft. Kultursoziologie der Gegenwart. Campus, Frankfurt a.M., 1992. 
